Kristi Haas

Boston College

School of Theology and Ministry

\title{
Full and Emptied: \\ Interpreting Christ's Divinity for Theologies of Religion
}

\begin{abstract}
The concept that "fullness" is to be found in Jesus Christ has been invoked to support the uniqueness of Jesus, including in the context of world religions. Yet the metaphorical sense of fullness is amenable to a variety of interpretations. Is this uniqueness the logical consequence of Christian faith, or an over-reliance on what amounts to a spatial metaphor? Are the uniqueness and primacy of Jesus meant only as praise, or does this also constitute a proposition about Jesus, vulnerable to the logic of non-contradiction? Is a lack or any partial lack of "fullness" to be found in any setting, if all things are created through, by, and for Jesus?

This paper explores the concept of the "fullness of truth" in its biblical context, as a doctrinal claim, and in contemporary interpretations in order to offer an analysis of "fullness" in Christ in light of the identity and call of the Church, the sacrament of God's salvific life. Treating fullness as an abstracted premise or proposition leads quickly to an ontotheological interpretation of Jesus' divinity. Instead, we would do well to learn the meaning of the metaphor by attending to its expressions in the life of the Church, a central one of which is the self-emptying love, the communion with which, we are promised, leads into all truth.
\end{abstract}

There exists a tension in Christian faith between the universality of God's love and the uniqueness of Christ. Christian theologies have grappled in various ways with the question: how do we reconcile God's will to save all people (see 1 Tim 2:4, 4:10; Ti 2; etc.) with the distinctiveness of Jesus Christ as the unique and absolute savior (Acts 4:12; Jn 3:16-19)? The documents of Vatican II explore this tension using a particular tone and vocabulary. The Dogmatic Constitution on Divine Revelation, Dei Verbum (1965), calls Jesus Christ "both the mediator and the fullness of all revelation." Meanwhile, The Declaration on the Relation of the Church to Non-Christian Religions, Nostra Aetate (1965), states that the Church "rejects nothing that is true and holy in these [other, non-Christian] religions,"2 implying that they may "contain"

\footnotetext{
${ }^{1}$ Paul VI, Dogmatic Constitution on Divine Revelation (Dei Verbum), November 18, 1965, §2. Liam Walsh, OP, in the Flannery edition of the Documents of Vatican II, translates it as "both the mediator and the sum total of revelation.” The scriptural references cited there are: Mt 11:27, Jn 1:14 and 17, 14:6, 17:1-3, 2 Cor 3:16 and 4:6, and Eph 1:3-14.

${ }^{2}$ Paul VI, Declaration on the Relation of the Church to Non-Christian Religions (Nostra Aetate), October 28, 1965, $\S 2$.
} 
such truth and holiness. Indeed, many people who are not Christian and who have never explicitly encountered Jesus Christ exhibit holiness and goodness that surpass that of Christians.

This paper explores the concept of the "fullness of truth" in Christ in its biblical context, as a doctrinal claim, and in contemporary interpretations. The concept that "the fullness of truth" is to be found in Jesus Christ has been invoked to support the case that Christianity is the best and truest religion. Yet this concept of fullness is amenable to a variety of interpretations due to the meaning of pleroma and to the sense in which it may be used metaphorically. This paper argues that the best interpretation of "fullness" in Christ must make reference to its implications for the identity and mission of the Church, because the Church's embodied life reveals the character of the fullness of truth in which it shares. In short, we can learn about "fullness" through what it implies about the Church, and we must do so in order to draw conclusions for theologies of religion.

The first section explores the concept of fullness in the New Testament. The focus is on the Letter to the Colossians, in which fullness (pleroma) is an abiding theme, and in particular on the hymn at the end of the first chapter. The second section turns to magisterial and dogmatic treatments of fullness as related to the Incarnation. The declaration Dominus Iesus (2000) insists that the concept of fullness of truth indicates the divine nature of Jesus Christ, and more specifically, that his human nature expresses his subjectivity, which is the divine Logos. This section also draws into the conversation Roger Haight's summary of how to conceive of fullness in Jesus (e.g., as constitutive or normative for salvation). The third section adds the concept of "self-emptying" (kénōsis) to the concept of fullness so as to clarify what is meant by "the fullness of truth." Finally, the synthesis proposes that the interpretation of fullness is most accurate and successful when it takes into account the implications of this fullness dwelling in Jesus Christ and in the Church. It is not something to be possessed, and it is not a source of 
worldly power or truth, but instead provides the source of the Church's reconciliation, perseverance in love, self-giving service, freedom, and transformative witness.

\section{Fullness of God: Colossians and the Fourth Gospel}

The entire phrase "fullness of truth" is not found in the New Testament, but instead it serves as a summary of several New Testament texts. In Jn 16:12-13 (NRSV CE ${ }^{3}$ ), Jesus says that the Spirit of Truth will guide the disciples to "all truth," even what he does not presently "tell." Two other key passages are found in the Letter to the Colossians and the Prologue of the Gospel of John. In both cases, "fullness" takes its meaning within the relationship among God, Jesus Christ, and his disciples.

At the same time, the Scriptural use of "fullness" (pleroma) is typically metaphorical. Just as the word "full" in English can carry quantitative or qualitative connotations depending on the context, so too can the Greek term mean either quantitative spatial fullness or qualitative completeness. When it refers to the fullness of divine truth, we might assume that the qualitative sense is meant, since God is not defined in spatial terms. Yet the Colossians hymn says that "in him all the fullness of God was pleased to $d w e l l$ ' (emphasis added), indicating through spatial imagery a primarily metaphorical sense of the term.

\section{The Letter to the Colossians: Sharing in Christ's Fullness}

The Letter to the Colossians encourages the community to remain steadfast in their life of faith, hope, and love in Christ. For the sake of this encouragement, the author illustrates the relationship among Christ, in whom dwells the fullness of God; all of creation; and the Church, which has access to this fullness through him who "is all and is in all" (Col 3:11). Sharing in this

\footnotetext{
${ }^{3}$ All citations of Scripture are from the New Revised Standard Version, Catholic Edition (1991).
} 
"fullness," the whole Church is called to show forth to the nations the truth, glory, reconciling power, and mystery of God.

The first use of "fullness" indicates the relationship in Christ among God, creation, and the Church. The hymn (Col 1:15-20) celebrates that all things have been created and reconciled in Christ. In order to understand the hymn's use of the "fullness of God," let us consider the hymn as a whole:

He is the image of the invisible God, the firstborn of all creation;

[God as subject: creation of cosmos in Christ]

for in him

all things in heaven and on earth were created, things visible and invisible, whether thrones or dominions or rulers or powers

all things have been created

through him and for him.

[Christ as subject in history: primacy in creation and Church]

He himself is before all things,

and in him all things hold together.

He is the head of the body, the Church;

is the beginning, the firstborn from the dead,

so that he might come to have first place in everything.

[God as subject: reconciliation in Christ]

\section{For in him}

all the fullness of God was pleased to dwell, and through him

God was pleased to reconcile to himself

all things, whether on earth or in heaven,

by making peace through the blood of his cross.
Christ's relation to God, relation to history/creation

Christ - locus of creation all created - past examples examples all created - past, ongoing

Christ - means and end

creation - past, primacy creation - present locus

Church-present locus Church - end, primacy

Christ, end of both Church and creation

Christ - locus of God all of God - subject

Christ - means

God - subject, end all of creation - object Christ-means

\footnotetext{
${ }^{4}$ Col 1:15-20 (NRSV, Catholic Edition). The emphasis and analysis are mine. Words in italics are exegetical, not part of the Scriptural text.
} 
The hymn plays with language of material quantity and time to point to the all-encompassing reconciliation Christ brings about between God and creation. Christ is both "the image of the invisible God" and "the firstborn of all creation." Two reasons are given for this dual title, each indicated by the word "for." First, he has these titles because spatially or relationally, all things from the visible to the invisible, from earth to heaven, were created in, through, and for him. He is the logic, means, and end of creation. Second, temporally, he is the beginning, present, and future of creation and of the Church. He is before all created things, and in him all things presently hold together. He is the present head of the Church, and he is both its foundation and its future, as the firstborn from the dead. Christ stretches across the cosmos and across time, ordering the entirety of both in his person. ${ }^{5}$ This encompassing or stretching has a particular intent: that Christ might come to have first place in everything.

One might think Christ could hold no more! Yet a second kind of "quantity" is also located in him, the "fullness of God." This second use of the concept of fullness shows the reason for Christ's primacy: he encompasses the vast expanse between creation and God. He orders all of creation and history as the one in whom "all the fullness of God was pleased to dwell." Thus, in this hymn, the "fullness of God" is inseparable from the meaning of "all things." The concepts function in parallel in such a way that the "fullness of God" explains how Christ could encompass all things, and to what end. Christ is praised as supreme - Christ in whom God locates, effects, and sums up his reconciling, re-creating power. In Christ, God's reconciling power is completely and ultimately powerful, because Christ takes up both the totality of creation and the fullness of God.

\footnotetext{
${ }^{5}$ The Third Edition of The Roman Missal (ICEL, 2010) includes a phrase with the same effect: "from the rising of the sun to its setting," which refers to all of time and all of the earth (Ps 113, Is 45, Mal 1).

${ }^{6}$ Most commentators prefer this translation, especially in light of Col 2:9, though the word "God" is not in the Greek text (Randy Sachs).
} 
The rest of the Letter to the Colossians is largely devoted to showing that the Church, the Body of Christ, shares in this fullness of God through Christ whom it praises as "before all things." The fullness of God has filled the Church as well. The second chapter states this explicitly:

For in him the whole fullness of deity dwells bodily, and you have come to fullness [or: are made full] in him ( $\mathrm{Col}$ 2:9-10, emphasis added). As in the hymn in Col 1, the word "for" indicates that this passage explains theologically what precedes it. Here, it tells why the Colossians should continue to live their faith steadfastly in Christ, not being taken "captive" by other philosophies (Col 2:6-8). As in Col 1, the "fullness" is modified by the genitive "of deity" (in Col 1, it is "of God"), and as in Col 1, the verb "dwell" indicates the manner of relation between this fullness and the person of Christ. While the hymn uses the past tense, however, indicating that something is accomplished already in Christ, Col 2 uses the present tense to indicate that this fullness still "dwells" in Christ. The Church's access to this fullness is ongoing. This is good news, as the call of the Church is to continue embodying Christ's reconciling power and glory. Indeed, in Col 2:9, the fullness of God is described not as abstract but as embodied: "the fullness of deity dwells bodily" in Christ (emphasis added). While the hymn emphasizes that the divine fullness of Christ is the source of his reconciling power, this latter passage emphasizes his embodied existence, including in the Church, which has been "made full" in him (Col 2:10).

The connotation of "fullness" in Colossians, then, has far more to do with the relationship among God, the Church, and creation than with theological debate about the person of Christ per $s e .^{7}$ That the author believes Christ is both divine and human (in other terms) is evident, but the purpose of this letter is ecclesiological. As Suzanne Watts Henderson explains: "his [Christ's]

\footnotetext{
${ }^{7}$ The doctrinal pronunciations regarding the two natures of Christ in one divine person came much later than the Pauline writings.
} 
bodily existence... continues in the life of the Church, which also serves as perpetual residence for that divine fullness. ${ }^{\prime 8}$ Speaking of fullness in Christ is mean to assert the identity and call of the Church in relation to Christ, its "head" and its hope (Col 1:18). Thus does the author of Colossians both assert that the community is "made full" $(\mathrm{Col} 2: 10)$ and pray that they be filled or brought to fullness (Col 1:9, 4:12). Henderson points out that the Septuagint text of the Old Testament makes a similar use of the concept of fullness: "Hellenistic Judaism portrays God's filling of creation as a declaration of God's expansive, all-encompassing dominion." the same themes of dominion in Colossians and notes resonance in the purpose of that dominion, namely, "renewal."10 God "dwells in" the Temple and in Christ so as to be effective for the People of God. The fullness of God in Christ is what creates and empowers the community of disciples to continue the reconciliation of "all things" that defines God's purpose in creation.

\section{The Gospel of John: From his Fullness, Grace upon Grace}

Is the same sense of the concept of fullness to be found in the Gospel of John? In the Prologue to the Gospel of John, "fullness" indicates the relationship of the Word-made-flesh to the Father, from whom his glory derives (Jn 1:14). This fullness was present from "the beginning" (Jn 1:1). Like the Letter to the Colossians, the Prologue points to the implications of this fullness for human beings, namely, that from the Word-made-flesh human beings have received "grace upon grace" (Jn 1:16).

The Prologue begins with the pre-existence of the Word. As in Colossians, the Gospel describes the role of the Son in creation: "All things came into being through him, and without

\footnotetext{
${ }^{8}$ Suzanne Watts Henderson, "God's Fullness in Bodily Form: Christ and Church in Colossians," The Expository Times 118, no. 4 (2007): 171.

${ }^{9}$ Ibid., 172.

${ }^{10}$ Ibid.
} 
him not one thing came into being" (Jn 1:3). Unlike Colossians, the Gospel uses the language of fullness even in relation to the birth of Jesus:

The Word became flesh and lived among us, and we have seen his glory, the glory as of a father's only son, full of grace and truth. (Jn 1:14)

The glory of the Word-made-flesh derives from the Word's relation to the Father; indeed, it is thanks to this relation that he is "full of grace and truth." This grace and this truth are not for Jesus' own sake, however. The Word became flesh in order to bring light, life, and, for those who believe in him, to bring "power to become children of God" (Jn 1:12). The author seems to be speaking from the experience of his own living community: "We" know he is "full of grace and truth" because "we have seen" it, and "From his fullness we have all received, grace upon grace" (Jn 1:16). As in Colossians, the "fullness" found in Christ is that divine life which is shared with the human community - the Church in the Letter to the Colossians, and the children of God in the Gospel of John. The mode of relation is again illustrated with the verb "dwell," indicating the metaphorical rather than solely propositional use of pleroma. The Prologue emphasizes the dynamics of belief and abiding in Christ rather than the embodiment of God's creation and reconciliation in Christ, yet in both passages, these implications for human beings derive from the fullness of God in Christ which he shares with us. The relation in Christ among God, creation, and human beings has implications for us, as source of grace, identity, power, and call. Christ brings "us" good news.

\section{Fullness, the Normativity of Christ, and Christological Doctrine}

Again, the common ground shared by Colossians and the Prologue of the Gospel of John is that "fullness" denotes metaphorically the divine aspect of Christ through which God's 
purpose for creation is effected. Indeed, the tradition has insisted that the fullness of truth is found in Jesus precisely because the person of Jesus is a divine Person, a divine subject. ${ }^{11}$ The Prologue of the Fourth Gospel indicates this theological fact most clearly when it says, in one verse, both that the Word became flesh and that he is revealed to us as full of truth (Jn 1:14). On the other hand, Colossians shows most clearly the effect of this Incarnation when it sings of the reconciliation of all things with God in Christ (Col 1:15-20). The life, death, and resurrection of Jesus are effective such that no other such incarnation is required or even possible. ${ }^{12}$ Thus the concept of "fullness of truth" has come to be associated not only with the completeness or sufficiency of Jesus as source of grace, truth, and power, but also, on the other hand, with the unique sufficiency of Jesus. Is belief of this uniqueness the logical consequence of Christian faith, or an over-reliance on the metaphor of "fullness"? Is the uniqueness and primacy of Jesus meant only as praise, or does it also constitute a claim about Jesus? Thus the tension between universality and uniqueness takes on a particular flavor when it comes to the concept of fullness. There are various attempts today to reconcile this sense of the uniqueness of Jesus with the fact of religious pluralism and with the goodness and holiness that are to be found in other religions. ${ }^{13}$ Nostra Aetate and subsequent documents developed the fundamental recognition that non-Christian religions "often reflect a ray of that truth which enlightens all men."14 Yet the simple fact of so much religious diversity has raised another, quite distinct question for theologians. Is God salvifically present everywhere, including to other religions as social and historical

\footnotetext{
${ }^{11}$ Congregation for the Doctrine of the Faith, Declaration on the Unicity and Salvific Universality of Jesus Christ and the Church (Dominus Iesus), June 16, 2000, $\$ 6$.

${ }^{12}$ See, e.g., CCC 639-648.

${ }^{13}$ Nostra Aetate, $\S 2$.

${ }^{14}$ Nostra Aetate, $\$ 2$.
} 
mediations of salvation? And, if so, then in what sense is Jesus the "both the mediator and the fullness of all revelation"15 (emphasis added)?

In his essay "Jesus and World Religions," Roger Haight summarizes the spectrum of positions concerning the uniqueness of Jesus Christ, which is at stake in this question of "fullness of truth." Haight thinks the most adequate way to organize the various answers is to ask whether someone thinks Jesus is "constitutive of" or "normative for" human salvation. Is Jesus "the cause of the salvation of all human beings," or does "Jesus [provide] the norm or measure of religious truth and God's salvation for all of humanity but does not [on the other hand] cause God's action for salvation that goes on outside the Christian sphere"? ${ }^{16}$ To transfer this question to the level of truth or revelation, rather than salvation, would be to ask: does Jesus embody all the truth that is to be encountered, or does Jesus provide the measure for truth without himself constituting or causing it? Colossians and the Prologue of the Fourth Gospel agree that the "fullness of God" found in Jesus belongs to a Person who is responsible for and in continual relationship with all of creation as its cause, its norm, and its telos. It is admittedly difficult to square this assertion with the reality of religious diversity as such (as Clooney explains), and with the reality of the coherence and evident holiness of particular other religions. Yet the assertion in Colossians of the supremacy of Christ in whom "the whole fullness of deity dwells bodily" (Col 2:9) is purposely construed in that text so as to dissuade Christians from seeking additional truth elsewhere.

Because his theological method emphasizes experience heavily as the source of truth claims, Roger Haight defines universalizing claims according to what he calls the experience of "universal relevance." Haight uses the category of "universal relevance" and the principle of

\footnotetext{
${ }^{15}$ Dei Verbum, §2.

${ }^{16}$ Roger Haight, "Jesus and World Religions," Modem Theology 12, no. 3 (July 1996): 322.
} 
non-contradiction to analyze analyzes the problem of religious diversity and the concepts of completeness, uniqueness, and primacy. He explains that Christians who encounter in Jesus an answer to "those issues that touch on the human as such," cannot conceive "the God of Christians... as a local God only for themselves.” Thus, they make claims about the universal saving power of Jesus. ${ }^{17}$ The principle of non-contradiction, then, rightly leads these Christians to reject the idea that some truth less than or contradictory to the truth in Christ should satisfy human beings. This is to treat Christ as a negative norm. Yet Haight also holds that the principle of non-contradiction is modified by the fact that the object of religious truth is transcendent; in such a case, contradiction can remain to some extent because language is inadequate for a transcendent object. ${ }^{18}$ One cannot determine so clearly whether a perceived contradiction is actually a contradiction, or whether a perceived agreement is actually a real agreement.

This perspective on normativity and contradiction seems to understate the role of contradiction in language about God. Philosophers such as Heidegger have insisted upon the gap between language and reality, especially with regard to God and/or Being. God is not fully knowable as the Supreme Being or Ultimate Cause as defined by metaphysics, and to ask whether Jesus is the "cause" of the salvation of all people is to use metaphysical concepts where the terms of symbolic exchange would be more suitable. ${ }^{19}$ Instead of treating the claim that Jesus constitutes all salvation and truth as a purposeful, symbolic claim, Haight seems to reject it as metaphysically untenable. Yet the original purpose of the claim is not metaphysical, at least in

\footnotetext{
${ }^{17}$ Haight, "World Religions," 327.

${ }^{18}$ Haight, "World Religions," 328. The rule that contradiction can be allowed in language about God is well known to mystical and apophatic theology.

${ }^{19}$ Here I draw distantly upon the analysis of Louis-Marie Chauvet in Chauvet, Louis-Marie. Symbol and Sacrament: A Sacramental Reinterpretation of Christian Existence. Trans. Patrick Madigan, S.J., and Madeleine Beaumont (Collegeville, Minn.: The Liturgical Press, 1995).
} 
Scripture and arguably in doctrine. Use of language to insert subjects into relationship with God allows for and may even require contradiction, tension, and conflict in a way that metaphysical language cannot allow. Haight and the Christians to whom he refers thus make the same mistake when they lean too much on the principle of non-contradiction with regard to religious truth. The point of religious language is not to settle finally on the correct concepts about God, but to maintain purposefully the conversation among them as a space in which God and subjects draw closer together in a posture of love. ${ }^{20}$

Another of Haight's points on the normativity of Christ is more fruitful regarding theologies of religion. He writes that Jesus' normativity, as far as it may or may not extend, is always historically mediated in limited ways: "the normativity of Jesus Christ only becomes actually operative by entering into new relationships within other systems of truth."21 Jesus the person is never accessed as such, but only through mediation, and so "[h]istorical relativity forces the Christian to define more exactly the content of what is mediated by Jesus."22 This will bring us yet again to the question of the "fullness" of God: what, exactly, is mediated? What is the character of this fullness of grace and truth, which dwells in Jesus and in the Church?

The question of the character of this fullness is precisely one of the themes defended and reiterated in the declaration Dominus Iesus (2000). The declaration defends the "unicity and salvific universality of Jesus Christ and the Church," and twice explains that the "fullness of truth" to be found in Jesus derives from his divine subjectivity. ${ }^{23}$ One might be tempted to object, the document admits, that "the truth about God cannot be grasped and manifested in its

\footnotetext{
${ }^{20}$ Chauvet, Symbol and Sacrament, 41-43.

${ }^{21}$ Haight, 330.

${ }^{22}$ Haight, 330.

${ }^{23}$ Dominus Iesus, $\S \S 5-6,10$.
} 
globality and completeness by any historical religion, neither by Christianity nor by Jesus Christ.",24 Yet doctrine of the Incarnation asserts precisely that God can be grasped, in one sense. "We have seen," "heard," and "touched" (Jn 1:14; 1 Jn 1:1) the one in whom this fullness is manifest. Although Christians profess this in faith, we cannot imagine concretely or empirically what it means that the "subject" of Jesus Christ is divine. Our profession of faith pertains to the relationship between God and humanity, not to the observable "ingredients" of Jesus. If once it was possible to imagine that some divine "substance" could "dwell" in human flesh, it is no longer, as the same critique of onto-theology that prevents our thinking of God primarily as "causing" effects in us also prevents our thinking of God as "present" in the way embodied beings are present. It lies beyond our experience, and thus beyond our imagination, to know the "content" of Jesus with which he is full. The next section therefore returns to Scripture with a different lens to explore the character of this divine subject come among us.

\section{Kénōsis and Fullness}

Given this post-onto-theological trajectory in contemporary living faith, which acknowledges so readily the distance between reality and language, how can the faith be studied and explained? Paradox and apparent contradiction are more easily tolerated, but they may even be necessary so as to capture the distances between language and reality and between God's ways and our ways. This is certainly the case concerning the concept of "fullness" in the New Testament. The fullness to be accessed in Christ cannot be understood without reference to selfemptying love. This section juxtaposes the concept of kénōsis, God's self-emptying love, with the concept of fullness studied in this paper.

\footnotetext{
${ }^{24}$ Dominus Iesus, $\$ 6$.
} 
This juxtaposition is especially relevant in today's intellectual culture. Peter Phan, in Being Religious Interreligiously: Asian Perspectives on Interfaith Dialogue, points out that neither narrative nor logic carries sufficient authority to engage postmodern people. If once, the narrative of the Incarnation inspired praise of the uniqueness of Jesus Christ as the one who reconciled all things to God, now that narrative presented as such can seem to us to exclude people who are just as beloved of God. If once, the logic of God's presence and miraculous causative power in Christ seemed to prove his uniqueness, now that logic presented as such seems unimaginable at best, potentially unjust to those who were not "chosen" to receive such a presence, and onto-theological in its depiction of God whose "presence" in Christ still transcends earthly modes of existence and causation.

In practice today, meaning does not rely as much on metanarratives or on the assertion of a natural cosmological order. Instead, Phan explains, the Gospel conveys meaning through "morosophia," foolish wisdom that brings life. ${ }^{25}$ The question of fullness is a case in point. A more compelling interpretation of the fullness of God in Christ appears as foolish wisdom, and indeed we can attune to the tension surrounding the Christ who at once presents the fullness of God and, on the other hand, empties himself. The "filling" of God with which Christ is filled, is revealed when, at another level, he empties himself of it. Thus, the juxtaposition between pleroma and kénōsis takes place in a "morosophistic" key, and the sense of "fullness" must account for its relation to self-emptying.

In the Gospel of John, we see God revealed not only as full of truth (as described above) but also as pouring himself out. These two metaphors, fullness and emptiness, both refer to the person of Christ: the one who "was in the beginning with God" (Jn 1:1), from whose "fullness

\footnotetext{
${ }^{25}$ Peter Phan, Being Religious Interreligiously: Asian Perspectives on Interfaith Dialogue (Maryknoll, NY: Orbis Books, 2004), 4-9.
} 
we have all received, grace upon grace" (Jn 1:16), who is "the Way, and the Truth, and the Life" (Jn 13:1-17; 14:6), is also the one who lowers himself to wash his disciples' feet. Jesus is the way and the truth in the sense that he has power to give the disciples a share in his relationship with the Father (Jn 14:2-3) and, in the terms used in Colossians, to reconcile all things to God. Yet the "truth" of Jesus is shown in that he, the master, both becomes a slave and commands his disciples, too, to wash one another's feet (Jn 13:13-15). Jesus has the authority to command this, and paradoxically, he who has authority is he who becomes a slave. Paul was attuned to this in his writing. He saw that the reconciling mission of Christ and the Church in Colossians requires the foolishness, weakness, humility, and self-emptying described in 1 Corinthians and Philippians 2. In a particular way, then, divine truth and self-emptying mutually define one another.

The relationship between Jesus' divine authority and Jesus' kénōsis has to do with the relationship between his divine nature and his human nature, but not in exact correspondence. It is not that the "self-emptying" Jesus does belongs to his humanity, while anything authoritative, miraculous, or wise Jesus does - the "fullness" - belongs to his divinity. Rather, there is no separation between the divine and human natures, and all of Jesus' actions are human expressions of the Word of God. As the Councils made clear at Nicaea, Chalcedon, and Constantinople, and as Dominus Iesus affirms, Jesus is both divine and human in such a way that his humanity belongs to the divine person, the Word, who is the subject of both natures. As a divine subject, Jesus was born as a human being, washed the disciples' feet, and died on the cross such that all of this human weakness could belong to and be attributed to the Word. 
Sarah Coakley provides concepts of kénōsis that clarify the interplay between fullness and emptying in the New Testament. ${ }^{26}$ What kind of fullness, power, and truth does God have in Christ, and what kind of emptying or weakness? She rightly finds, through a feminist analysis, that some uses of kénōsis or "self-emptying" are problematic when they are employed at the expense of human dignity. As for another possible interpretation, God did not literally conceal or "pause" that power for a time in order to become accessible to human beings, all the while remaining intrinsically strong. There is no true kénōsis in this account; this is Docetism.

Furthermore, a God who was intrinsically weak in human terms did not appropriate the language of power in order to show that what humans think of as weak is actually strong. There is no kénōsis in this account, either.

According to Coakley, the weakness revealed in Christ is the weakness of vulnerability, and the power tied up in vulnerability of Christ is the power of transformation. In his humanity, Coakley agrees, Jesus refuses forms of worldly power, and yet he expresses a different kind of divine power. This indicates that the nature of divine power (and, for our purposes, divine truth) includes the power to transform, reconcile, and even sometimes subvert human relationships, through their participation in God. This is the transformative power about which Mary proclaimed, "He has cast down the mighty from their thrones, and has lifted up the lowly. $\mathrm{He}$ has filled the hungry with good things, and the rich he has sent away empty" (Lk 1:53).

\section{Conclusion: The "Content" of Fullness}

Let us add to the conversation, then, the point that God's power is thus expressed and made perfect in weakness - and that it is through becoming vulnerable in service to others that Christians exercise the transformative power God has given to them in Christ. Does the same

\footnotetext{
${ }^{26}$ Sarah Coakley, Powers and Submissions: Spirituality, Philosophy and Gender (Wiley-Blackwell, 2002), 3-68.
} 
dynamic apply to the truth of God, the fullness of which is in Christ? Can we say that in some sense, God's truth in its fullness is made perfect in obscurity, or in some kind of foolishness?

The truth of God is never so fully encountered in propositions as in the person of Christ. There is substantial scriptural evidence that Jesus might allow himself as God to be encountered in the particularity of other religions precisely because he has created, ordered, and reconciled all things in love. If he is encountered in such particularities, then he is encountered as truth, since his truth and his person are inseparable. Thus, in the person of Jesus, we can describe a specific kind of compatibility between wisdom and foolishness, truth and obscurity, assertion and reservation. The wisdom, truth, and proclamation of God's love and saving power are absolutely to be found in Christ, and they are found most fully by those who share in the existential "posture" of Jesus' person through faith, hope, and love - through trust and wonder, joyful expectation, and compassionate service.

The compatibility of truth and obscurity in Jesus also carries an eschatological dimension. This existential Christian posture includes a certain kind of foolishness and uncertainty, an expectant reservation that awaits the encounter with Christ ever promised. The fullness of truth in Christ is eschatologically realized but for us, in history, it is not received with the clarity of the eschaton. Furthermore, the metaphor of "possession" may wrongly lead us to think that we can finally attain fullness. God cannot be possessed as objects can, and to think one has finally come into total possession of the truth of Christ is to have misunderstood an intersubjective relationship. In our mediated, symbolic order the "truth" of a subject can never be finally actualized or fully encountered until his or her sharing in Resurrection. The only exception to this is Christ, the firstborn of the dead. He is fully actualized, having risen, and yet the truth of Christ can also never be finally possessed or completely encountered now because 
his person is only accessible to us in history through mediation (especially and certainly through the Sacraments). God's fullness dwells in him, and we dwell in him but also in history. He has given fully of his truth, and we cannot fully attain to it; the day of the Lord is here, and we await the day of the Lord. In these two ways - because truth in Christ is personal, and because truth in Christ is eschatological - truth and obscurity are compatible for Christians.

Therefore, the principle of non-contradiction ought not to apply "as usual" in speech about God. The purpose of the Colossians hymn is not to offer propositions about God; it is to praise God, to draw the Church into closer communion with Jesus Christ through whom they share the fullness of God. Even less is the language of fullness within the Colossians hymn intended to delineate "how much of God" Jesus reveals and how much is or is not available elsewhere. The challenge for theologies of religions is, then, to remember that the Christ who is the Way, the Truth, and the Life, who is "filled" with what "fills" God, is also the God who commands and manifests that truth in love, vulnerability, compassion, and service. That love is the truth, the way, and the source of life. To say that Jesus is full of grace and truth is to say that in Jesus, we encounter and share lovingly in the love, vulnerability, compassion, and service of God-for-us, in the ek-stasis of God that gives to us our own life, our own freedom, our own ekstasis in God. When a belief strays from its purpose, to bring disciples into deeper faith, hope, and love, it has gone astray.

Jesus said clearly: “'I still have many things to say to you, but you cannot bear them now. When the Spirit of truth comes, he will guide you into all the truth; for he will not speak on his own, but will speak whatever he hears, and he will declare to you the things that are to come" (Jn 16:12-13). It is in divesting ourselves of proud certainty and preferring instead to enact Jesus' faith, hope, and love that we draw nearer to the truth of his person. There is a sense in which we 
must follow the call of Jesus to "come and see" where he lives (Jn 1:39), and to come and see the fullness of truth that dwells in him. This includes the mode of our relationship with texts and people of other religions, and it is the encounter with goodness and holiness outside the Church, with the beauty found in the diversity of religions, that has given rise to this understanding and articulation of fullness.

Paul (or, the author of Colossians) does not refer to the fullness of God in isolation. Colossians was written to encourage Christian living, and it does not allow for a deductive logic moving from theology to Christology to ecclesiology. It is, however, amenable to an inductive analysis. We can draw inferences, hints, and guesses about God from the author's vision of how the Church shares in the fullness of God. The Church, it its identity as the Body of Christ, shares in the fullness of God insofar as it is called to extend God's reconciling, merciful, saving love to the world. We share in the fullness of God in the form, also, of a call to prepare our heart, vulnerable as Christ's, to meet in each moment a deeper invitation into the fullness of truth given in Christ. 